\title{
Selection before backcross during exotic germplasm introgression
}

\author{
N. Ochanda ${ }^{\text {a }}$, J. Yu ${ }^{\text {a,* }}$, P.J. Bramel ${ }^{\text {b }}$, A. Menkir ${ }^{c}$, M.R. Tuinstra ${ }^{d}$, M.D. Witt ${ }^{\mathrm{e}}$ \\ ${ }^{a}$ Department of Agronomy, Kansas State University, 2004 Throckmorton Hall, Manhattan, KS 66506, United States \\ ${ }^{\mathrm{b}}$ International Crops Research Institute for the Semi-Arid Tropics (ICRISAT), Patancheru 502324, India \\ ${ }^{\mathrm{c}}$ International Institute of Tropical Agriculture (IITA), Oyo Road, PMB 5320, Ibaban, Nigeria \\ d Department Of Agronomy, Purdue University, 1150 Lilly Hall of Life Sciences, West Lafayette, IN 47907, United States \\ e Southwest Kansas Research Center, Garden City, KS 67846, United States
}

\section{A R T I C L E I N F O}

\section{Article history:}

Received 6 May 2008

Received in revised form 3 November 2008

Accepted 24 January 2009

\section{Keywords:}

Backcross

Breeding method

Introgression

Plant breeding

Selection

\begin{abstract}
A B S T R A C T
Introgression of genes from exotic germplasm into breeding populations can broaden the genetic base of crop improvement. Only a very small percentage of genetic variability has been used in crop breeding programs. Traditionally, $\mathrm{F}_{1}$ plants are used to backcross to the adapted lines or populations. An alternative approach is to backcross the $F_{2}$ individuals selected for agronomic acceptability. Our objective was to determine whether selection before backcross would lead to more progenies with both high yield and acceptable levels of agronomic performance than direct backcross without selection. To test the feasibility of the proposed approach, we conducted parallel experiments in which two exotic sorghum accessions were crossed to two adapted sorghum parents and further backcrossing was conducted with either $F_{1}$ or selected $F_{2}$ plants. Fifty random $S_{1}$ families were evaluated in three test environments. Although selection before backcross resulted in a higher frequency of families with maturity equal to or earlier than those of the adapted parents, no consistent changes in grain yield and plant height were observed between populations with and without selection. Similar results were found with either an inbred or a population as the recurrent parents. Given these findings and the extra generation required, we do not recommend selection before backcross in the process of introgression of exotic germplasm.
\end{abstract}

() 2009 Elsevier B.V. All rights reserved.

\section{Introduction}

Among methods available in traditional plant breeding, including single cross, three-way cross, backcross, and cyclic population improvement, backcross remains the common choice to introgress the beneficial alleles from exotic germplasm into adapted breeding materials (Eaton et al., 1986). Backcrossing maintains the desired genetic complexes already present in the adapted genotypes while allowing recombination between exotic and adapted genomes. Various theoretical and empirical studies have demonstrated that introgression of unadapted germplasm of low yield potential required at least one backcross to the adapted parent to recover or increase the yield potential of the adapted parent (Lambert and Leng, 1965; Dudley, 1982; Cox and Frey, 1984).

Although exotic germplasm has found a greater use in sorghum [Sorghum bicolor (L.) Moench] compared with other crops, adapted elite germplasm continues to be the preferred source of favorable alleles in U.S. sorghum breeding programs (Bramel-Cox and Cox,

\footnotetext{
* Corresponding author.

E-mail address: jyu@ksu.edu (J. Yu).
}

1989). The predominance of two sorghum introductions (SC170 and SC110) in the released parental lines and their significant contribution to the commercial hybrid germplasm pool demands a need to diversify the sorghum germplasm pool (Duncan et al., 1991). Besides adapted inbreds, introgression can also be conducted with an adapted population as the recurrent parent. Bramel-Cox and Cox (1989) proposed that an adapted population allows each allele or combinations of alleles from the exotic donor parent to express in a much broader background and thus increases the opportunities to extract favorable epistatic combinations between the exotic and adapted alleles. Indeed, Menkir et al. (1994a) found that a higher percentage of lines with acceptable grain yield, plant height, and maturity was derived with the population backcrossing scheme than with the inbred backcrossing scheme.

The traditional introgression procedure consists of backcrossing an unselected sample of the $F_{1}$ to a recurrent parent, either inbred or population. If the primary trait (e.g., grain yield) is complexly inherited but fairly independent of secondary traits, such as plant height or maturity, selection in $F_{2}$ population for segregates that most closely resemble the recurrent parent for the secondary traits before backcross would enhance the introgression of beneficial alleles from the exotic parent. LeRoy et al. (1991) 
found that selection for small seed size during backcrossing in the introgression of genes for small seed size from the wild soybean (Glycine soja) into the cultivated species (Glycine max) increased the frequency of backcross progeny with smaller seed weights compared with backcrossing without selection. A very limited number of field based studies have been conducted on breeding method because of the difficulties involved in this kind of studyseed availability, sample size, and multiple environment testing (Arbelbide and Bernardo, 2004; Tabanao and Bernardo, 2005).

No study conducted to evaluate the effectiveness of selection before backcross in the introgression of exotic germplasm to adapted breeding materials in sorghum has been reported. Our objective was to determine whether selection before backcross would lead to more progenies with both high yield and acceptable levels of agronomic performance in plant height and days to flowering than direct backcross without selection. We tested this hypothesis by backcrossing two exotic sorghum accessions (Segeolane and SC408) to two adapted sorghum parents, an inbred (CK60) and a population (KP9B), and comparing grain yield, plant height, and days to flowering of the families derived with or without selection.

\section{Materials and methods}

\subsection{Backcross scheme}

The four matings used in this study were derived from the crosses of two adapted sorghum parents (CK60 and KP9B) with two exotic sorghum accessions (Segeolane and SC408) (Fig. 1). Overall, two backcross schemes were compared across four different genetic backgrounds. For backcross without selection, the usual way of backcrossing $F_{1}$ to the adapted parent was conducted, whereas backcrossing selected $F_{2}$ individuals to the adapted parents was done for backcross with selection scheme (Fig. 1). The four different genetic backgrounds were derived from the combinations of two exotic accessions and two adapted parents. As described in the later paragraphs $50 \mathrm{~S}_{1}$ families were tested for each of the eight resulting populations (Fig. 1).

CK60 is an old adapted three-dwarf inbred line with a genetic male sterile gene $\left(\mathrm{ms}_{3} \mathrm{~ms}_{3}\right)$ to facilitate crossing, and KP9B is a

\begin{tabular}{|c|c|c|}
\hline \multirow[t]{2}{*}{ Adapted parent } & \multicolumn{2}{|c|}{ Exotic accession } \\
\hline & Segeolane & SC408 \\
\hline CK60 (inbred) & NS $S$ & NS $S$ \\
\hline KP9B (population) & NS $S$ & NS $S$ \\
\hline
\end{tabular}

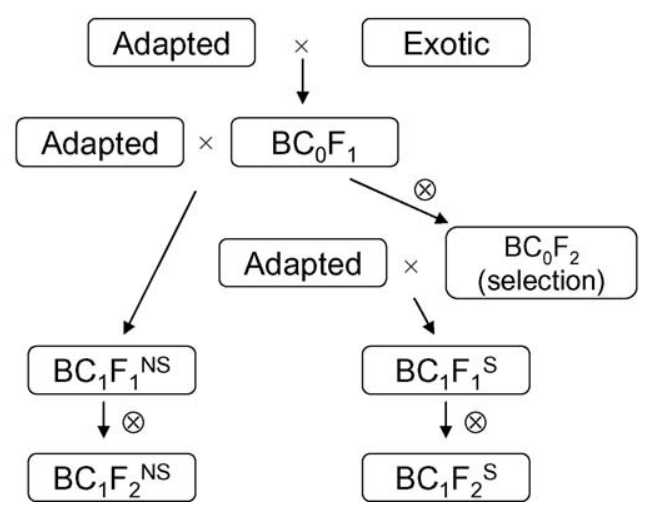

Fig. 1. Different breeding schemes with or without selection before backcross with either an inbred or a population as the recurrent parent. NS, non-selection; S, selection. broad-based random mating population with genetic male sterility developed at Kansas State University (Zavala-Garcia et al., 1992). Segeolane is an accession of race Kafir cultivated as a landrace in Botswana, and SC408 is a conversion line derived from a Caudatum-Guinea landrace from Nigeria, which was released in 1974 following four generations of backcrossing in the TAES-USDA conversion program (Quinby, 1974; Rosenow and Dahlberg, 2000).

In the CK60 matings, bulk pollen was collected from 5 to 10 plants of each exotic parent and used to pollinate 8-14 genetic male sterile plants of CK60. A bulk mixture of the $\mathrm{BC}_{0} \mathrm{~F}_{1}$ plants of each mating was sown for backcrossing to CK60 and for selfpollination to produce $\mathrm{BC}_{0} \mathrm{~F}_{2}$. The unselected $\mathrm{BC}_{1} \mathrm{~F}_{1}$ was obtained by pollinating each of 10-12 genetic male sterile plants of CK60 with bulk pollen taken randomly from 8 to $10 \mathrm{BC}_{0} \mathrm{~F}_{1}$ plants in each mating. The selected $\mathrm{BC}_{1} \mathrm{~F}_{1}$ was obtained by pollinating a similar number of genetic male sterile plants of CK60 with bulk pollen taken from 8 to $10 \mathrm{BC}_{0} \mathrm{~F}_{2}$ plants selected to have agronomic acceptability on the basis of plant height, flowering time, and panicle type. Notice that it was not possible to consider grain yield at this stage because selection was done prior to or during flowering time. As in the regular plant breeding process, this selection is based on the judgment of the breeders to select against plants that are tall, late maturing, or have a loose panicle. More than 100 male-fertile $F_{2}$ plants were harvested from the unselected and selected $\mathrm{BC}_{1} \mathrm{~F}_{2}$ generations of the matings of CK60 with Segeolane and SC408.

Because of the heterogeneity in KP9B, randomly chosen male sterile $\left(\mathrm{ms}_{3} \mathrm{~ms}_{3}\right)$ plants of $\mathrm{KP9B}$ were crossed individually with plants of each exotic accession to produce 22-36 plant-to-plant crosses $\left(\mathrm{BC}_{0} \mathrm{~F}_{1}\right)$. Each plant-to-plant cross was sown in a separate row for crossing to the adapted population and for self-pollination to produce the $\mathrm{BC}_{0} \mathrm{~F}_{2}$. Each $\mathrm{BC}_{0} \mathrm{~F}_{1}$ was mated individually to randomly chosen sterile plants of $\mathrm{KP} 9 \mathrm{~B}$ to form the unselected $\mathrm{BC}_{1} \mathrm{~F}_{1}$. The selected $\mathrm{BC}_{1} \mathrm{~F}_{2}$ was obtained by crossing the most agronomically acceptable $\mathrm{BC}_{0} \mathrm{~F}_{2}$ plants of each $\mathrm{BC}_{0} \mathrm{~F}_{1}$ to randomly chosen male sterile plants of KP9B. At least 10 male-fertile $F_{2}$ plants were harvested from the unselected and selected $\mathrm{BC}_{1} \mathrm{~F}_{2}$ generations of every plant-to-plant cross in the matings of KP9B with Segeolane and SC408. For all four matings, $50 \mathrm{~F}_{2}$-derived $\mathrm{S}_{1}$ families were randomly chosen from the selected and unselected populations to enter the field test.

\subsection{Field experiments}

Field experiments were conducted at three environments (i.e., location-year combination): Garden City, KS, in 1991, Garden City, KS, in 1992, and Manhattan, KS, in 1992. Each experiment consisted of 50 randomly $F_{2}$-derived $S_{1}$ families from the selected and unselected $\mathrm{BC}_{1}$ of all four matings (eight populations) and the four parents (CK60, KP9B, Segeolane, and SC408). The experiments were conducted in two replications of a blocks-in-replication design with a split-plot arrangement. The eight mating-backcross method populations were assigned randomly to eight main plots. The $50 \mathrm{~F}_{2}$-derived lines from each population were split into two sets of 25 lines. Each set, along with four entries of the adapted parent and one entry of the exotic parent, were assigned randomly to the two subplots in the main plot. The subplot was a single row $6 \mathrm{~m}$ in length; rows were $75 \mathrm{~cm}$ apart.

Soil types were a Kahola silt loam (fine-silty, mixed, Mesic Cumulic Hapluidoll) at Manhattan and a Ulysses silt loam (linesilty Mesic Aridic Haplustoll) at Garden City. The trials were planted on May 20, 1991, in Garden City, June 20, 1992, in Garden City, and May 23, 1992, in Manhattan. Before planting, $56 \mathrm{~kg} \mathrm{ha}^{-1}$ nitrogen was applied in both years at each location. Weeds were controlled at Garden City with a preemergence application of 4-$5 \mathrm{~kg} \mathrm{ha}^{-1}$ propachlor and at Manhattan with $9.41 \mathrm{~kg} \mathrm{ha}^{-1}$ Ramrod- 
Table 1

Mean squares from the combined analysis of variance of five traits of each mating within $\mathrm{BC}_{1}$ populations tested in three environments.

\begin{tabular}{|c|c|c|c|c|c|c|}
\hline \multirow[t]{2}{*}{ Source of variation } & \multicolumn{2}{|l|}{ Grain yield } & \multicolumn{2}{|c|}{ Days to flowering } & \multicolumn{2}{|l|}{ Plant height } \\
\hline & Unselected & Selected & Unselected & Selected & Unselected & Selected \\
\hline \multicolumn{7}{|l|}{ CK60 $\times$ Segeolane } \\
\hline Entry & $1.44^{* *}$ & $1.98^{* *}$ & $4.15^{* *}$ & $4.17^{* *}$ & $4.82^{* *}$ & $4.69^{* *}$ \\
\hline Entry $\times$ environment & 0.93 & $0.97^{* *}$ & 0.40 & $0.44^{*}$ & 0.22 & 0.29 \\
\hline \multicolumn{7}{|l|}{ CK60 $\times$ SC408 } \\
\hline Entry & $1.82^{* *}$ & $2.33^{* *}$ & $2.16^{* *}$ & $3.40^{* *}$ & $3.90^{* *}$ & $3.42^{* *}$ \\
\hline Entry $\times$ environment & $1.60^{* *}$ & $0.86^{*}$ & $0.91^{* *}$ & 0.57 & $0.54^{* *}$ & $0.63^{* *}$ \\
\hline \multicolumn{7}{|l|}{ KP9B $\times$ Segeolane } \\
\hline Entry & 1.53 & $1.71^{* *}$ & $3.06^{* *}$ & $3.33^{* *}$ & $2.60^{* *}$ & $3.78^{* *}$ \\
\hline Entry $\times$ environment & $1.24^{* *}$ & 0.97 & $0.96^{* *}$ & $0.90^{* *}$ & $0.95^{* *}$ & $0.75^{* *}$ \\
\hline \multicolumn{7}{|l|}{$\mathrm{KP9B} \times \mathrm{SC} 408$} \\
\hline Entry & $2.05^{* *}$ & $2.88^{* *}$ & $2.86^{* *}$ & $2.22^{* *}$ & $2.63^{* *}$ & $3.38^{* *}$ \\
\hline Entry $\times$ environment & $0.97^{* *}$ & $0.82^{* *}$ & $0.94^{* *}$ & $1.25^{* *}$ & $1.02^{* *}$ & $0.76^{* *}$ \\
\hline
\end{tabular}

"Significantly different at $P=0.05$ level.

Significantly different $P=0.01$ level.

Atrazine. Plots were thinned to final populations of 131,000 plants ha $^{-1}$ at Manhattan and 87,000 plants ha $^{-1}$ at Garden City. During the growing season, plots received $396 \mathrm{~mm}$ of precipitation at Garden City, 1991, 397 mm at Garden City, 1992, and $576 \mathrm{~mm}$ at Manhattan, 1992. In 1991, all experimental plots in Garden City were machine harvested, and grain yield of individual plots was recorded. Plots were hand harvested in both Garden City and Manhattan in 1992, and grain yield was obtained from an area $1 \mathrm{~m}$ long and $75 \mathrm{~cm}$ wide in each plot. Days to flowering were recorded as the number of days from planting to the date when at least $50 \%$ of the panicles in a plot were shedding pollen. After anthesis, plant height was measured from the ground to the panicle tip and recorded as the average of $2-8$ plants per plot.

\subsection{Statistical analysis}

Analysis of variance for all traits within each mating and backcross method was computed for individual environments and combined over environments. Raw data for each trait were standardized with a block mean of zero and standard deviation of 1 to adjust for a significant block effect as suggested by ZavalaGarcia et al. (1992). Standardized data were used to compute analyses of variance for each population within an environment and overall. Replications, blocks, and lines were assumed to be random. Genetic variance estimates for each population were estimated by equating the observed mean squares to expected mean squares and solving for the appropriate component. Approximate standard errors for genetic variance estimates were calculated according to the method of Hallauer and Miranda (1981).

The independent $t$-test was used to test for differences in the selected and unselected backcross populations (Ott, 1988). The difference between the mean yield of an $\mathrm{F}_{2}$-derived line and its parent was tested by using Fishers protected LSD (Ott, 1988) with the standard error calculated from the individual population error mean square. A positive transgressive segregate was defined as a derived line with a mean yield that exceeded its adapted parent's mean yield by at least two standard deviations. The significance of the difference between the mean of the 10 top-yielding lines and the mean of the adapted parent was tested by using the LSD calculated from the individual population error mean square (Cox and Frey, 1984). Significance of differences among the parents was tested with the LSD calculated from the error mean squares pooled over populations.

\section{Results}

In the combined analysis of variance, interactions of entry by environment were significant for grain yield, days to flowering, and plant height for most of the matings in both selected and unselected populations (Table 1). Significant variation for grain yield occurred among entries in all populations except in the unselected KP9B $\times$ Segeolane population. The variations captured by entry and entry by environment interaction were comparable between selected and unselected populations across all traits. In general, the genetic variance estimates for the selected populations were similar to those of the unselected populations across traits. Although significant entry by environment effects were observed across traits, many of these interactions were mainly due to scale change, and the differences in trait values were generally consistent across environments. Therefore, we present the results from the combined analysis across environments unless otherwise specified to show the difference across environments.

\subsection{Mean performance}

Mean grain yields across all $\mathrm{BC}_{1} \mathrm{~F}_{2}$-derived families in Garden City, 1991, Garden City, 1992, and Manhattan, 1992 were 3.9, 5.8, and $8.1 \mathrm{mg} \mathrm{ha}^{-1}$, respectively. Mean grain yields were highest in Manhattan, 1992 because of greater precipitation and more favorable growing conditions. Generally, both adapted parents, CK60 and KP9B, flowered earlier than the two exotic accessions, Segeolane and SC408, and were significantly shorter (Table 2). Of two exotic accessions, Segeolane was significantly taller and later flowering than SC408 across all environments. As expected, significant genotype by environment interaction led to varied mean grain yields of these four parents across environments.

Compared with unselected populations, a reduced days to flowering was observed for the selected populations across all matings and environments except for KP9B $\times$ Segeolane in Garden City, 1992 (Table 3). Reductions in the mean days to flowering were significant for most of the populations. Plant height of the selected population was either unchanged or significantly reduced compared with that of the unselected populations in most matings except for KP9B $\times$ Segeolane. For grain yield, out of 12 comparisons, there were six cases in which the selected population yielded significantly lower than its counterparts without selection but only two cases in which a significant increase in grain yield was observed in the selected population. 
Table 2

Mean grain yield, days to flowering, and plant height for the four sorghum parents (KP9B, CK60, Segeolane, and SC408) in three environments.

\begin{tabular}{|c|c|c|c|}
\hline Environment and parent & $\begin{array}{l}\text { Yield } \\
\left(\mathrm{mg} \mathrm{ha}^{-1}\right)\end{array}$ & $\begin{array}{l}\text { Days to } \\
\text { flowering }\end{array}$ & $\begin{array}{l}\text { Plant height } \\
(\mathrm{cm})\end{array}$ \\
\hline \multicolumn{4}{|l|}{ Garden City, 1991} \\
\hline CK60 & $3.23 \mathrm{~b}^{*}$ & $72 b$ & $100 \mathrm{~b}$ \\
\hline КР9В & $4.52 \mathrm{a}$ & $72 \mathrm{a}$ & $111 a$ \\
\hline Segeolane & $4.56 a$ & $81 \mathrm{~b}$ & $176 c$ \\
\hline SC408 & $3.23 \mathrm{~b}$ & $76 c$ & $127 d$ \\
\hline \multicolumn{4}{|l|}{ Garden City, 1992} \\
\hline СK60 & $5.93 b$ & $70 \mathrm{~b}$ & $131 \mathrm{a}$ \\
\hline КР9В & $5.84 \mathrm{bc}$ & $67 a$ & $126 a$ \\
\hline Segeolane & $6.43 a$ & $77 \mathrm{c}$ & $186 b$ \\
\hline SC408 & $6.43 \mathrm{ac}$ & $70 \mathrm{~b}$ & $149 c$ \\
\hline \multicolumn{4}{|l|}{ Manhattan, 1992} \\
\hline CK60 & $7.50 \mathrm{~b}$ & $75 b$ & $143 b$ \\
\hline КР9В & $8.70 a$ & $71 \mathrm{a}$ & $148 a$ \\
\hline Segeolane & $7.70 \mathrm{~b}$ & $79 c$ & $219 c$ \\
\hline SC408 & $7.60 \mathrm{~b}$ & $74 \mathrm{~b}$ & $185 d$ \\
\hline
\end{tabular}

" With each environment, estimates of trait mean followed by the same letter were not significantly different at $P=0.05$ level.

\subsection{Progeny distribution}

Grain yield of progenies as expressed in standardized units in the selected and unselected populations fell symmetrically around the adapted parents, CK60 and KP9B (Fig. 2). There was no obvious shift in the frequency distribution of the derived lines toward either higher or lower yielding classes across environments. Likewise, the proportions of positive transgressive segregates for grain yield did not have a consistent increase pattern across matings.

The 10 highest-yielding families of each mating for the selected and unselected populations were compared with the adapted parent for grain yield, days to flowering, and plant height (Table 4). The top families from the unselected and selected populations
Table 3

Means for grain yield, days to flowering, and plant height for the selected and unselected backcross populations of sorghum grown in three environments.

\begin{tabular}{|c|c|c|c|c|}
\hline Environment and mating & Selection & $\begin{array}{l}\text { Yield } \\
\left(\mathrm{mg} \mathrm{ha}^{-1}\right)\end{array}$ & $\begin{array}{l}\text { Days to } \\
\text { flowering }\end{array}$ & $\begin{array}{l}\text { Plant height } \\
(\mathrm{cm})\end{array}$ \\
\hline \multicolumn{5}{|l|}{ Garden City, 1991} \\
\hline \multirow[t]{2}{*}{ CK60 $\times$ Segeolane } & Unselected & 3.21 & 73 & 118 \\
\hline & Selected & $4.11^{*}$ & $72^{*}$ & 116 \\
\hline \multirow{2}{*}{ CK60 $\times$ SC408 } & Unselected & 3.46 & 74 & 123 \\
\hline & Selected & 3.36 & $67^{*}$ & $118^{*}$ \\
\hline \multirow[t]{2}{*}{ KP9B $\times$ Segeolane } & Unselected & 4.62 & 72 & 121 \\
\hline & Selected & $3.63^{*}$ & $70^{*}$ & $137^{*}$ \\
\hline \multirow{2}{*}{$\mathrm{KP9B} \times \mathrm{SC} 408$} & Unselected & 3.97 & 71 & 118 \\
\hline & Selected & $3.35^{*}$ & $70^{*}$ & $114^{*}$ \\
\hline \multicolumn{5}{|l|}{ Garden City, 1992} \\
\hline \multirow[t]{2}{*}{ CK60 $\times$ Segeolane } & Unselected & 5.80 & 71 & 144 \\
\hline & Selected & 6.00 & $69^{*}$ & 152 \\
\hline \multirow[t]{2}{*}{$\mathrm{CK} 60 \times \mathrm{SC} 408$} & Unselected & 5.78 & 69 & 165 \\
\hline & Selected & $5.27^{*}$ & $67^{*}$ & $148^{*}$ \\
\hline \multirow[t]{2}{*}{ KP9B $\times$ Segeolane } & Unselected & 5.51 & 68 & 138 \\
\hline & Selected & $6.03^{*}$ & $69^{*}$ & $152^{*}$ \\
\hline \multirow[t]{2}{*}{ KР9B $\times$ SC408 } & Unselected & 4.66 & 70 & 143 \\
\hline & Selected & 4.93 & $68^{*}$ & $133^{*}$ \\
\hline \multicolumn{5}{|l|}{ Manhattan, 1992} \\
\hline \multirow{2}{*}{ CK60 $\times$ Segeolane } & Unselected & 8.23 & 76 & 164 \\
\hline & Selected & $7.38^{*}$ & $74^{*}$ & 161 \\
\hline \multirow[t]{2}{*}{$\mathrm{CK} 60 \times \mathrm{SC} 408$} & Unselected & 8.96 & 75 & 187 \\
\hline & Selected & $7.26^{*}$ & $73^{*}$ & $162^{*}$ \\
\hline \multirow[t]{2}{*}{ KP9B $\times$ Segeolane } & Unselected & 7.48 & 73 & 162 \\
\hline & Selected & 7.40 & $72^{*}$ & $179^{*}$ \\
\hline \multirow[t]{2}{*}{ KP9B $\times$ SC408 } & Unselected & 8.49 & 72 & 173 \\
\hline & Selected & $7.90^{*}$ & 72 & $157^{*}$ \\
\hline
\end{tabular}

Significantly different from the unselected population mean at $P=0.05$ level.
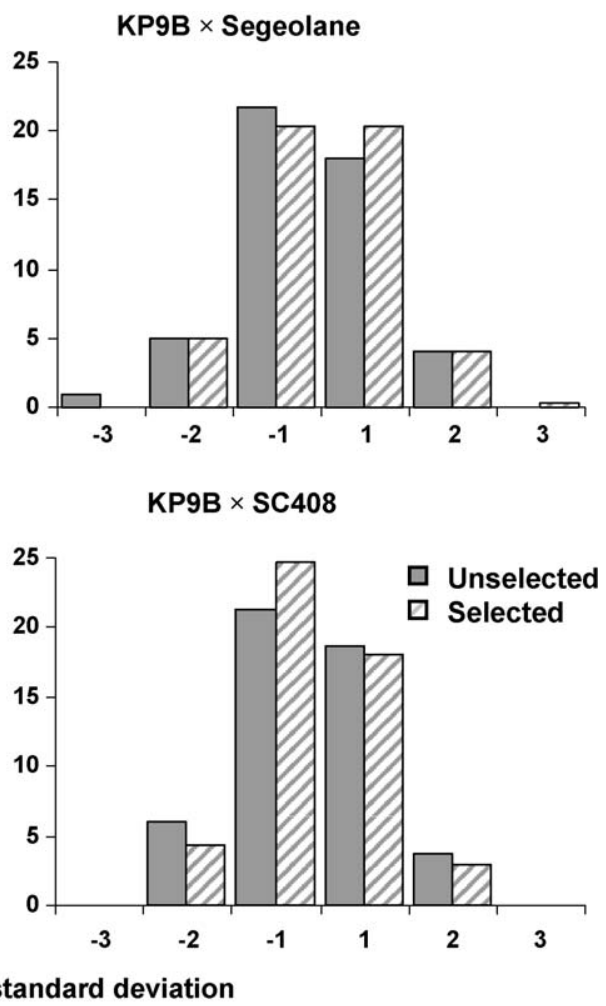

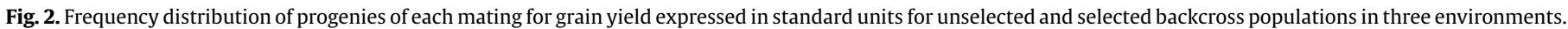


Table 4

Mean grain yield, days to flowering, and plant height expressed as percentages of the adapted parent for the 10 highest yielding lines of each mating in selected and unselected backcross populations of sorghum.

\begin{tabular}{lllll}
\hline Mating & Selection & Yield & $\begin{array}{l}\text { Days to } \\
\text { flowering }\end{array}$ & Plant height \\
\hline CK60 $\times$ Segeolane & Unselected & 146 & 102 & 117 \\
& Selected & 132 & 103 & 117 \\
CK60 $\times$ SC408 & Unselected & 142 & 101 & 124 \\
& Selected & 118 & 96 & 113 \\
KP9B $\times$ Segeolane & Unselected & 119 & 104 & 111 \\
& Selected & 122 & 102 & 123 \\
KP9B $\times$ SC408 & Unselected & 118 & 102 & 113 \\
& Selected & 112 & 99 & 108 \\
\hline
\end{tabular}

across all matings yielded higher than the adapted parents. This increased yield of the top families was accompanied mostly by a significant increase in plant height.

\subsection{Agronomic acceptability and grain yield}

Because the adapted parents were the most acceptable in terms of days to flowering and plant height, we further examined the proportions of families falling within and outside the range of the adapted parent (CK60 or KP9B) for days to flowering and plant height (Table 5). In the current study, agronomic acceptability was defined by days to flowering and plant height. An agronomically acceptable plant height or flowering date was either less than or equal to that of the adapted parent. The proportion of families with acceptable days to flowering was greater for selected populations across matings, but no consistent pattern was observed for plant height. Across all environments, there were few significant correlations among grain yield, days to flowering, and plant height in both selected and unselected populations.

An agronomically acceptable family was defined as having at least a $10 \%$ higher grain yield than the adapted parent but with days to flowering and plant height close to that of the adapted parent. Contrary to the expectation, the overall proportion of agronomically acceptable families obtained from unselected populations (3.7\%) was higher than that obtained from the selected populations $(1.8 \%)$ (Table 6$)$. This trend was generally consistent across environments.

\section{Discussion}

One of the major constraints associated with using exotic germplasm in an applied plant breeding program is lack of an efficient method to introduce favorable alleles not currently present or present at low frequency in the adapted gene pool
Table 6

Number of sorghum lines that had at least a $10 \%$ higher grain yield than the adapted parent and were within the range of the adapted parent for days to flowering and plant height in three environments.

\begin{tabular}{lrrl}
\hline Mating & Garden City, 1991 & Garden City, 1992 & Manhattan, 1992 \\
\hline $\begin{array}{l}\text { CK60 } \times \text { Segeolane } \\
\text { Unselected }\end{array}$ & 10 & 12 & 8 \\
Selected & 6 & 4 & 0 \\
CK60 $\times$ SC408 & & & \\
$\quad$ Unselected & 4 & 0 & 0 \\
Selected & 0 & 0 & 0 \\
$\begin{array}{lll}\text { KP9B } \times \text { Segeolane } \\
\text { Unselected }\end{array}$ & 4 & & \\
Selected & 2 & 0 & 0 \\
KP9B $\times$ SC408 & & 4 & 2 \\
$\quad$ Unselected & 0 & & 0 \\
Selected & 0 & 6 & 4 \\
\hline
\end{tabular}

without reducing the frequency of existing favorable alleles or lowering the performance of the population (Dudley, 1982; Halward and Wynne, 1991). Though the traditional $\mathrm{F}_{2}$ or $\mathrm{BC}_{1}$ based breeding methods are still widely used (Bernardo, 2002), different types of modification have been examined (e.g., random matting $\mathrm{F}_{2}$ or $\mathrm{BC}_{1}$ population before selfing and using adapted populations rather than inbreds for introgression). However, empirical studies in maize indicated that random mating before selfing in $\mathrm{F}_{2}$ (Altman and Busch, 1984; Covarrubias-Prieto et al., 1989; Lamkey et al., 1995) or $\mathrm{BC}_{1}$ (Arbelbide and Bernardo, 2004) populations are not useful in applied breeding programs. Another type of modification is replacing the recurrent inbred parent with an adapted population (Menkir et al., 1994a).

In the present study, selection for adaptation traits before backcross was compared with the regular backcross without selection by using four matings derived from two adapted parents and two exotic accessions. These matings were chosen to cover a broader range of scenarios. The genetic background of an adapted parent has previously been shown to have an influence on the expression of introgressed genes from exotic accessions (Isleib and Wynne, 1983; Eaton et al., 1986; Bramel-Cox and Cox, 1989; Menkir et al., 1994a, 1994b). The two exotic parents, Segeolane and SC408, had diverse origins. For the adapted inbred CK60, each locus was expected to be fixed, whereas the broad-based population КР9B was expected to contain a large number of segregating loci.

Genetic variance is an important factor that can predict the usefulness of adapted by exotic backcrosses for selection. Introgressing exotic germplasm into adapted populations can affect both the level and variability of useful traits within the population. To improve a quantitative trait when using backcrossing to introgress exotic germplasm into an adapted popula-

Table 5

Proportion of derived lines with days to flowering or plant height falling within and outside the range of the adapted parent.

\begin{tabular}{|c|c|c|c|c|c|c|c|}
\hline \multirow[t]{2}{*}{ Mating } & \multirow[t]{2}{*}{ Selection } & \multicolumn{3}{|c|}{ Days to flowering } & \multicolumn{3}{|c|}{ Plant height } \\
\hline & & Less than & Within & More than & Less than & Within & More than \\
\hline \multirow[t]{2}{*}{ CK60 $\times$ Segeolane } & Unselected & 35 & 25 & 39 & 22 & 21 & 57 \\
\hline & Selected & 59 & 18 & 23 & 21 & 19 & 60 \\
\hline \multirow[t]{2}{*}{$\mathrm{CK} 60 \times \mathrm{SC} 408$} & Unselected & 36 & 24 & 40 & 4 & 1 & 95 \\
\hline & Selected & 80 & 18 & 4 & 2 & 6 & 92 \\
\hline \multirow[t]{2}{*}{ KP9B $\times$ Segeolane } & Unselected & 23 & 37 & 39 & 30 & 9 & 60 \\
\hline & Selected & 31 & 34 & 31 & 9 & 8 & 83 \\
\hline \multirow[t]{2}{*}{$\mathrm{KP9B} \times \mathrm{SC} 408$} & Unselected & 30 & 31 & 39 & 25 & 9 & 66 \\
\hline & Selected & 33 & 34 & 27 & 35 & 17 & 48 \\
\hline
\end{tabular}


tion, a plant breeder aims to increase the mean sufficiently without reducing the genetic variance below the level required for selection (Cox, 1984). Our results showed that selection during backcrossing did not result in any significant reduction in the genetic variance for the different traits across environments. Thus, the use of selection would not be detrimental to genetic gain in this population.

There are two possible explanations for the results of this study. First, because only a restricted sample of gametes were used to make the selected backcrosses in the $F_{2}$, random changes in gene frequencies (genetic drift) could have occurred and led to the reduced means in grain yield in the selected backcross populations we observed. Second, genetic architecture of plant height in these populations may be more complex than days to flowering and subject to epistatic and/or genotype by environment interaction that made the selection of short plant in individual $\mathrm{F}_{2}$ plants not effective. Other reasons such as sample size in progeny testing also may have affected the results. A larger sample size would be desirable but would have increased the difficulty involved in conducting the field experiment over multiple environments. On the other hand, because we essentially replicated the experiment over multiple populations with different genetic backgrounds, sample size would not be a plausible explanation for what we observed. More field testing is desirable but would be difficult to carry out given the amount of seeds available and would make the testing process less similar to the actual breeding process.

Our study has implications for other breeding practices. In wheat breeding, for example, breeders often exploit the three-way cross besides $\mathrm{F}_{2}$ or $\mathrm{BC}_{1}$ as the segregating population (Alan Fritz, personal communication). Instead of selfing the $F_{1}$ or crossing the $\mathrm{F}_{1}$ to the adapted parent, breeders may choose a different adapted parent to cross with $F_{1}$. This scheme was designed to combine superior alleles from two elite parents while incorporating the desirable biotic and abiotic stress tolerance traits from the unadapted inbred. Although the exact breeding purposes in a three-way cross may be different from the breeding scheme in our current study, our findings suggested that little gain is likely to be expected if a similar selection before backcross is conducted in the three-way cross.

In summary, selection among $\mathrm{F}_{2}$ plants for agronomic acceptability before backcross to the adapted parent did not generate more agronomically acceptable families with both higher yield and acceptable levels of plant height and flowering time. The selection implemented in this breeding scheme also requires an additional season in a typical growing environment. Consequently, on the basis of results from the current study, we do not recommend selection before backcross in either inbred or population-based introgression process.

\section{Acknowledgements}

The authors thank the Kansas State Board of Agriculture/Kansas Grain Sorghum Commission for their financial support for this project. Contribution no. 09-140-J from the Kansas Agricultural Experiment Station.

\section{References}

Altman, D.W., Busch, R.H., 1984. Random intermating before selection in spring wheat. Crop Sci. 24, 1085-1089.

Arbelbide, M., Bernardo, R., 2004. Random mating before selfing in maize $\mathrm{BC}_{1}$ populations. Crop Sci. 44, 401-404.

Bernardo, R., 2002. Breeding for Quantitative Traits in Plants. Stemma Press, Woodbury, MN.

Bramel-Cox, P.J., Cox, T.S., 1989. Use of wild germplasm in sorghum improvement. In: Wilkinson, D. (Ed.), Proceedings of 43rd Annual Corn and Sorghum Industry. Res. Con. American Seed Trade Assoc., Washington, D.C., pp. 13-26.

Covarrubias-Prieto, J., Hallauer, A.R., Lamkey, K.R., 1989. Intermating F2 populations of maize. Genetika 21, 111-125.

Cox, T.S., 1984. Expectations of means and genetic variances in backcross populations. Theor. Appl. Genet. 68, 145-153.

Cox, T.S., Frey, K.J., 1984. Genetic variation for grain yield and related traits in a sorghum introgression population. Theor. Appl. Genet. 68, 145-153.

Dudley, J.W., 1982. Theory for transfer of alleles. Crop Sci. 22, 631-637.

Duncan, R.R, Bramel-Cox, P.J., Miller, F.R. 1991. Contribution of introduced sorghum germplasm to hybrid development in the USA. In: Use of Plant Introductions in Cultivar Development, Part 1, CSSA Special Publication no. 17. p. 69-102.

Eaton, D.L., Busch, R.H., Youngs, Y.L., 1986. Introgression of unadapted germplasm into adapted spring wheat. Crop Sci. 26, 473-477.

Hallauer, A.R., Miranda, J.B., 1981. Quantitative Genetics in Maize Breeding. Iowa State University Press, Ames.

Halward, T.M., Wynne, J.C., 1991. Generation mean analysis for productivity into diverse peanut crosses. Theor. Appl. Genet. 82, 784-792.

Isleib, T.G., Wynne, J.C., 1983. Heterosis in testcrosses of 27 exotic peanut cultivars. Crop Sci. 23, 832-841.

Lambert, R.J., Leng, E.R., 1965. Backcross response of two mature plant traits for certain corn-teosinte hybrids. Crop Sci. 5, 239-241.

Lamkey, K.R., Schnicker, B.J., Melchinger, A.E., 1995. Epistasis in an elite maize hybrid and choice of generation for inbred development. Crop Sci. 35, 12721281.

LeRoy, A.R., Fehr, W.R., Cianizio, S.R., 1991. Introgression of genes for small seed size from Glycine soja into G. max. Crop Sci. 31, 693-697.

Menkir, A., Bramel-Cox, P.J., Witt, M.D., 1994a. Comparisons of methods for introgressing exotic germplasm into adapted sorghum. Theor. Appl. Genet. 89, $233-$ 239.

Menkir, A., Bramel-Cox, P.J., Witt, M.D., 1994b. Selection for agronomically acceptable inbred lines in adapted $\times$ exotic backcross populations of sorghum developed using two introgression schemes. Crop Sci. 34, 1084-1089.

Ott, L., 1988. An Introduction to Statistical Methods and Data Analysis, third ed. PWS-Kent Publishing Co., Boston.

Quinby, J.R., 1974. Sorghum Improvement and the Genetics of Growth. Texas A\&M University Press, College Station.

Rosenow, D.T., Dahlberg, J.A., 2000. Collection, conversion and utilization of sorghum. In: Smith, C.W., Frederiksen, R.A. (Eds.), Sorghum: Origin, History, Technology, and Production. John Wiley \& Sons, New York, pp. 305-328.

Tabanao, D., Bernardo, R., 2005. Genetic variation in maize breeding populations with different numbers of parents. Crop Sci. 45, 2301-2306.

Zavala-Garcia, F., Bramel-Cox, P.J., Eastin, J.D., Witt, M.D., Andrews, D.J., 1992. Increasing the efficiency of crop selection for unpredictable environments. Crop Sci. 32, 51-57. 